\title{
Homology problems in cephalopod morphology: deceptive (dis)similarities between different types of 'caecum'
}

\author{
Dirk Fuchs ${ }^{1}$ (D)
}

Received: 18 October 2018 / Accepted: 22 January 2019/Published online: 6 March 2019

(C) Akademie der Naturwissenschaften Schweiz (SCNAT) 2019

\begin{abstract}
Homoplasy is a common phenomenon in the evolution of the Cephalopoda. Many homology problems accordingly light up phylogenetic debates. The initial segment of the siphuncle, the so-called 'caecum', is one of these characters difficult to be unambiguously evaluated. Although rarely discussed, the caecum of the endocochleate decabrachian Spirula is traditionally seen as a plesiomorphy directly inherited from its ectocochleate ancestors. However, the Spirula caecum must be-according to recent phylogenetic analyses_-derived from a substructure of the belemnoid protoconch. Here, I review the morphology of different types of ectocochleate and endocochleate protoconchs. Detailed comparisons show that belemnoid protoconchs are structurally closer to the bactritoid/ammonoid protoconch than to the spiruloid protoconch. The most striking difference between the caecum of Spirula and bactritoids or ammonoids concerns its ultrastructure, which is lamello-fibrillar nacre (Spirula nacre or nacre type II) in the former and organic in the latter. The Spirula caecum is consequently equivalent to the first septum, while in bactritoids/ammonoids, the caecum is a separate structure independent of the proseptum. To conclude, the spiruloid protoconch (including caecum) has been derived either from a belemnitid or diplobelid protoconch. Similarities between the bactritoid/ammonoid and spiruloid caecum are superficial and only concern its shape.
\end{abstract}

Keywords Cephalopoda · Coleoidea · Caecum · Protoconch · Homology · Homoplasy

\section{Introduction}

Already eighteenth century scientists knew that the siphuncular tube runs through the chambers of the pearly Nautilus (e.g. Walch 1768). Hyatt (1872: p. 62) was the first to call the blind sac-like end of the siphuncle in the protoconch (= initial chamber) of Nautilus, goniatites, and ammonites the "siphonal coecum", which is today commonly known as the "caecum". Only 2 years later, Munier-Chalmas (1874) confirmed a caecum in the protoconch of living Spirula. Present experts widely agree that the usually non-mineralized caecum belongs to the cephalopod ground patterns occurring in all subgroups. The study of cephalopod literature allows us to assume that

Editorial Handling: C. Klug.

\section{Dirk Fuchs}

drig.fuchs@gmail.com

1 SNSB-Bayerische Staatssammlung für Paläontologie und Geologie, Richard-Wagner-Str. 10, 80333 Munich, Germany there is no doubt that the recent Spirula and thus the spirulid lineage (somehow) inherited the caecum and the prosiphon from ectocochleate ancestors (e.g. Naef 1922; Jeletzky 1966; Dauphin 1976; Donovan 1977; Drushchits et al. 1977; Bandel and Boletzky 1979; Barskov 1982; Reitner and Engeser 1982; Berthold and Engeser 1987; Engeser and Bandel 1988; Boletzky 1993; Landman et al. 1996; Haas 1997, 2003; Fuchs 2006; De Baets et al. 2012). For, instance, Jeletzky (1966: p. 80) emphasized in this context: "It is impossible to assume that the caecum and prosipho could reappear in the Sepiida [including spirulids].....under these circumstances one is forced to derive the Sepiida from some orthoconic ectocochlia either directly or via some other intermediate coleoid forms."

So far, only very few authors have criticized this view (e.g. Hewitt and Jagt 1999; Fuchs et al. 2012a, b; 2013). This general lack of scientific debate appears surprising, as homoplasies are common in the evolutionary history of cephalopods (e.g. Lindgren et al. 2012; Fuchs 2012; Fuchs and Iba 2015). The presumed homology between the ammonoid and spirulid caecum suggests that the Spirula- 
type caecum represents an old plesiomorphic feature directly inherited from its Devonian bactritoid ancestors. In fact, the spirulid caecum can be traced back to Late Cretaceous precursors (Cyrtobelus), but earlier 'spiruloid' caeca are surprisingly unknown in the coleoid fossil record (Fuchs et al. 2012a). This enormous time gap (DevonianLate Cretaceous), the total absence of a caecum in sepiid cuttlebones, and the fact that the siphuncle does not enter the lumen of the protoconch in belemnoid coleoids cast doubts on the putative homology between the ammonoid and spirulid caecum and highlights the necessity to scrutinize the detailed morphology of the different protoconch and caecum types (Fig. 1). A literature review combined with own SEM studies revealed striking structural differences and allows to address open questions such as whether caeca evolved multiple times or whether it is possible that the position of the initial siphuncular segment varied through cephalopod phylogeny.

\section{A posteriori: the (non-)homology of the caecum in different phylogenetic scenarios}

\section{Nineteenth century view: belemnoids are stem decabrachians}

Naef (1922) followed the view of many nineteenth century workers and considered the Spirula caecum to be inherited from their ectocochleate ancestors unaltered. This assumption was, however, mainly based on the erroneous view that belemnoid coleoids likewise possessed a caecum in the protoconch.

\section{Twentieth century view: 'Belemnoidea' is a monophyletic and extinct side branch (Fig. 2a)}

The absence of a caecum in belemnoid coleoids and the presence of a first non-mineralized and non-perforated septum (closing membrane) led many twentieth century

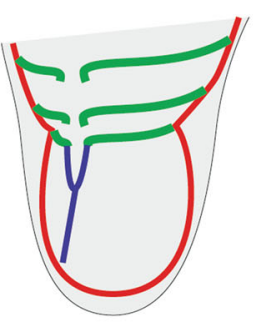

Groenlandibelidae (Cyrtobelus)

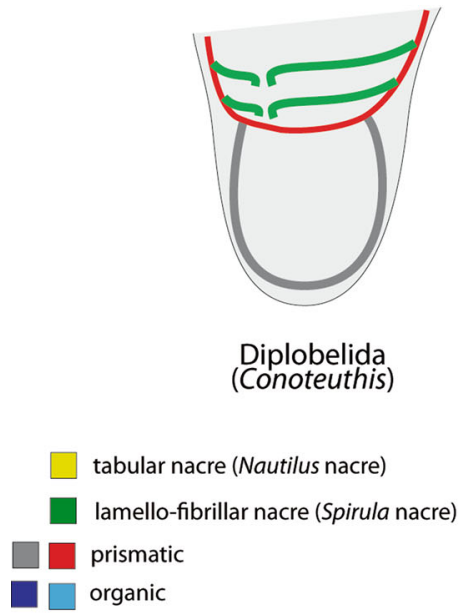

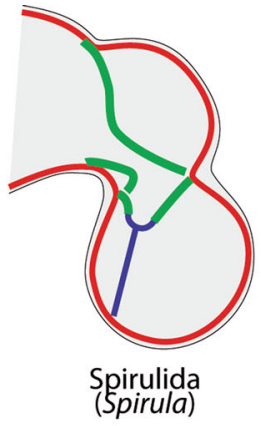

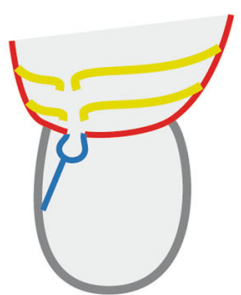

Bactritoidea / Ammonoidea

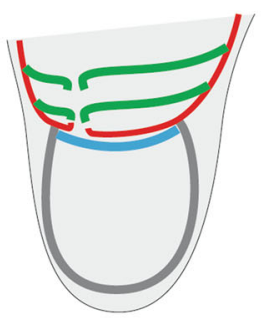

Diplobelida (Tauriconites)

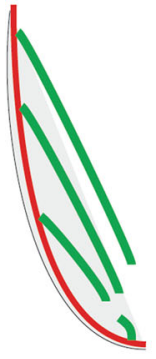

Sepiida (Sepia)

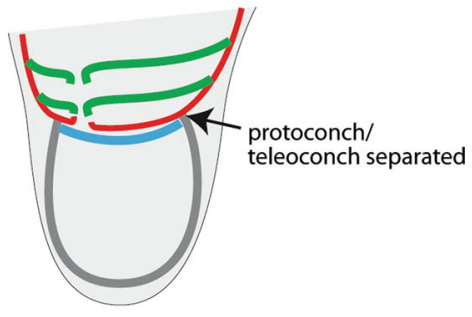

Belemnitida /

Aulacoceratida

Fig. 1 The bactritoid/ammonoid type of protoconch compared to the variety of coleoid types of protoconchs 

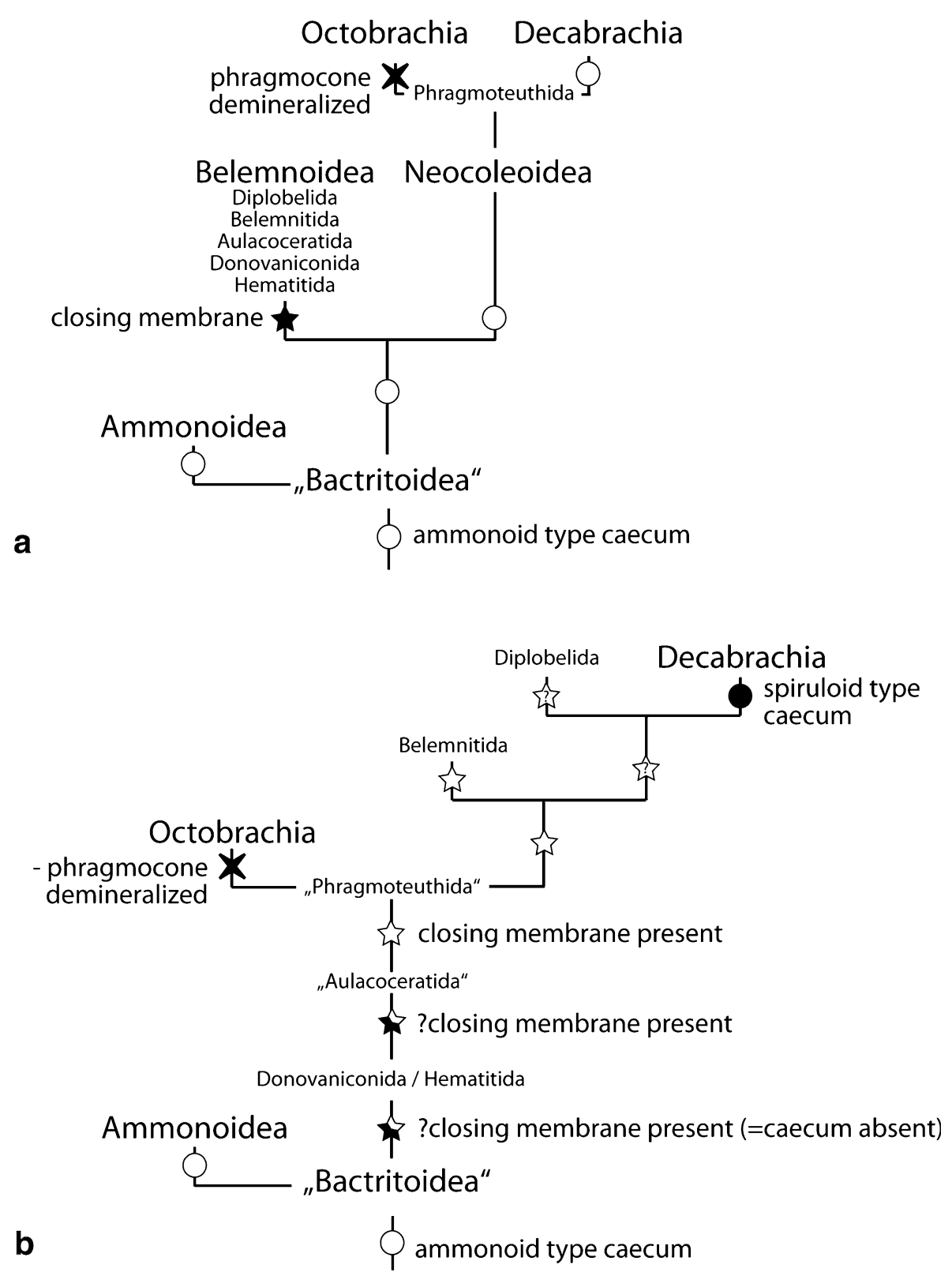

\section{apomorphic s plesiomorphic}

Fig. 2 Two phylogenies indicating what happened to the ammonoid type of caecum if the Belemnoidea is a monophyletic and extinct side branch of the Neocoleoidea (a) or belemnoid orders Belemnitida and

workers to consider the 'Belemnoidea' (Aulacoceratida, Phragmoteuthida, Belemnitida, Diplobelida) as a monophyletic group that became extinct without descendants (e.g. Jeletzky 1966; Donovan 1977; Engeser and Bandel 1988; Engeser 1990; Doyle et al. 1994; Haas 1997). For Jeletzky (1966: p. 9), the spirulid caecum is clearly a homologous reminiscence of their ectocochleate ancestors: "Presence of caecum and prosipho allies the Sepiida [including spirulids] instead with ectocochlian Cephalopoda (...) which almost

\section{polarization uncertain}

Diplobelida represent stem groups of the Decabrachia ('Belemnoidea' and 'Neocoleoidea' are paraphyletic) (b)

invariably possess a caecum....". Hence, the 'Belemnoidea' school treated the absence of a caecum in the protoconch (i.e. the presence of a closing membrane) as an autapomorphy of the 'Belemnoidea' (Fig. 2a). Such a topology (e.g. Doyle et al. 1994) places the Phragmoteuthida outside the 'Belemnoidea' as the stem group of the 'Neocoleoidea' (Decabrachia plus Octobrachia).

This view was initially supported by the idea that belemnoid arms were equipped with hooks instead of 
suckers (Haas 1989; hook-bearing 'Palaeocoleoidea' vs. sucker-bearing 'Neocoleoidea'). However, the first critique on this 'Neocoleoidea' concept came from Boletzky (1992) who reminded that the two different arm crown modifications in Decabrachia (transformation of arm pair IV) and Octobrachia (transformation of arm pair II) point to a diphyletic origin of 'Neocoleoidea' and thus to paraphyletic 'Belemnoidea'. More recent observations have shown that belemnoids indeed bore both uniserial suckers and biserial hooks (Fuchs et al. 2010).

\section{Twenty-first century view: revival of the 'belemnoids are stem decabrachians' concept (Fig. 2b)}

Hewitt and Jagt (1999) were the first to explicitly argue against the presumed homology between the typical cephalopod caecum and the spirulid caecum and instead suggested an adaptive convergence as a result of similar hatching depths. The latter authors considered diplobelid belemnoids as the root stock of sepiids and indeed Fuchs et al. (2012b) discovered striking differences between the diplobelid and belemnitid types of protoconchs. In addition, Fuchs et al. (2013) found a mosaic of diplobelid and spirulid shell features in Early Cretaceous Longibelus. Cladistic analyses by Sutton et al. (2015) and Klug et al. (2016) exposed the belemnoids as stem groups of the Decabrachia (rather than stem groups of both Decabrachia and Octobrachia). In such a topology, the Spirula caecum must have been indirectly derived from a belemnoid protoconch substructure rather than directly from bactritoid ancestors (Fig. 2b).

Hence, a posteriori phylogenetic conclusions are equivocal. It is therefore necessary to corroborate morphological and ultrastructural details of the cephalopod caecum and its associated protoconch characters.

\section{A priori: comparative morphology of the cephalopod protoconch}

\section{Caecum and prosiphon}

In protoconch terminologies, the caecum generally describes the first segment of the siphuncle. "It protrudes into the initial chamber through the septal foramen of the first septum...." (Stenzel in Sweet 1964: p. K46). The caecum is mostly bulbous, pear, or sausage shaped. Adorally, the caecum is usually attached to the first mineralized septum, whereas its apex can end freely, be in contact with the initial shell wall, or be fixed to the latter via the stripelike prosiphon.

Coleoidea. In recent Spirula, we have a comparatively consistent and precise picture of the caecum morphology (e.g. Naef 1922; Mutvei 1964; Jeletzky 1966; Bandel and Boletzky 1979; Fuchs 2006). Ultrastructurally, the caecum wall is composed of lamello-fibrillar nacre (nacre type II, Spirula nacre). It is adorally attached to the strongly constricted inner prismatic layer of the conotheca (Fig. 3a-f). Its free-standing apex is covered by an organic cap, which is connected to the ventral protoconch wall via the stripelike prosiphon.

Jeletzky (1966) first described the caecum of the Late Cretaceous spirulid Cyrtobelus in detail (his Groenlandibelus; see Fuchs et al. 2012a). Unlike Spirula, the caecum of Cyrtobelus is sausage shaped and attached to a well-developed first lamello-fibrillar septum (Fig. 4a, b). The prosiphon is rather short since the caecum is situated very closely to the ventral protoconch wall. Unfortunately, the septal and siphuncular complex of Cenozoic spirulids (e.g. Beloptera, Vasseuria, Spirulirostra) is usually not preserved.

In modern sepiid cuttlebones, a caecum (and prosiphon) does not exist. Meyer $(1989,1993)$ claimed to have found a caecum with prosiphon in early sepiids Ceratisepia (Maastrichtian-Palaeocene) and Belosaepia (Eocene). This interpretation is, however, still awaiting confirmation since the author could not provide appropriate photographs of the studied thin sections, which are in addition no more available for re-studies (pers. comm. Didier Merle, MNHN, Paris). We thus cannot exclude the possibility that Meyer's drawings have been biased by the system of Jeletzky (1966), who placed Spirula and Cyrtobelus along with Sepiida.

The existence of a spirulid caecum in the ground pattern of belemnoids as Naef (1922) assumed has been shown to be erroneous (see 'closing membrane').

Bactritida. Records of caeca in bactritoids are rare (e.g. Erben in Sweet 1964; Mapes 1979). Well-preserved specimens described by Doguzhaeva (2002) did not preserve a caecum, but she indirectly assumed their existence owing to the presence of a foramen in the first septum. We currently lack knowledge of texture and composition since caeca are mostly preserved as internal moulds. A specimen figured by Mapes (1979: pl. 32, Figs. 8, 9) suggests attachment to the retrochoanitic septal necks of the first septum. Jeletzky (1966) explained the lack of a prosiphon in bactritids as a diagenetical artefact. However, a bactritid prosiphon is still unknown.

Ammonoidea (Fig. 4c). Authors commonly agree that the ammonoid type of caecum was originally organic, adorally attached to the prismatic proseptum, and adapically connected to the protoconch wall via the likewise 

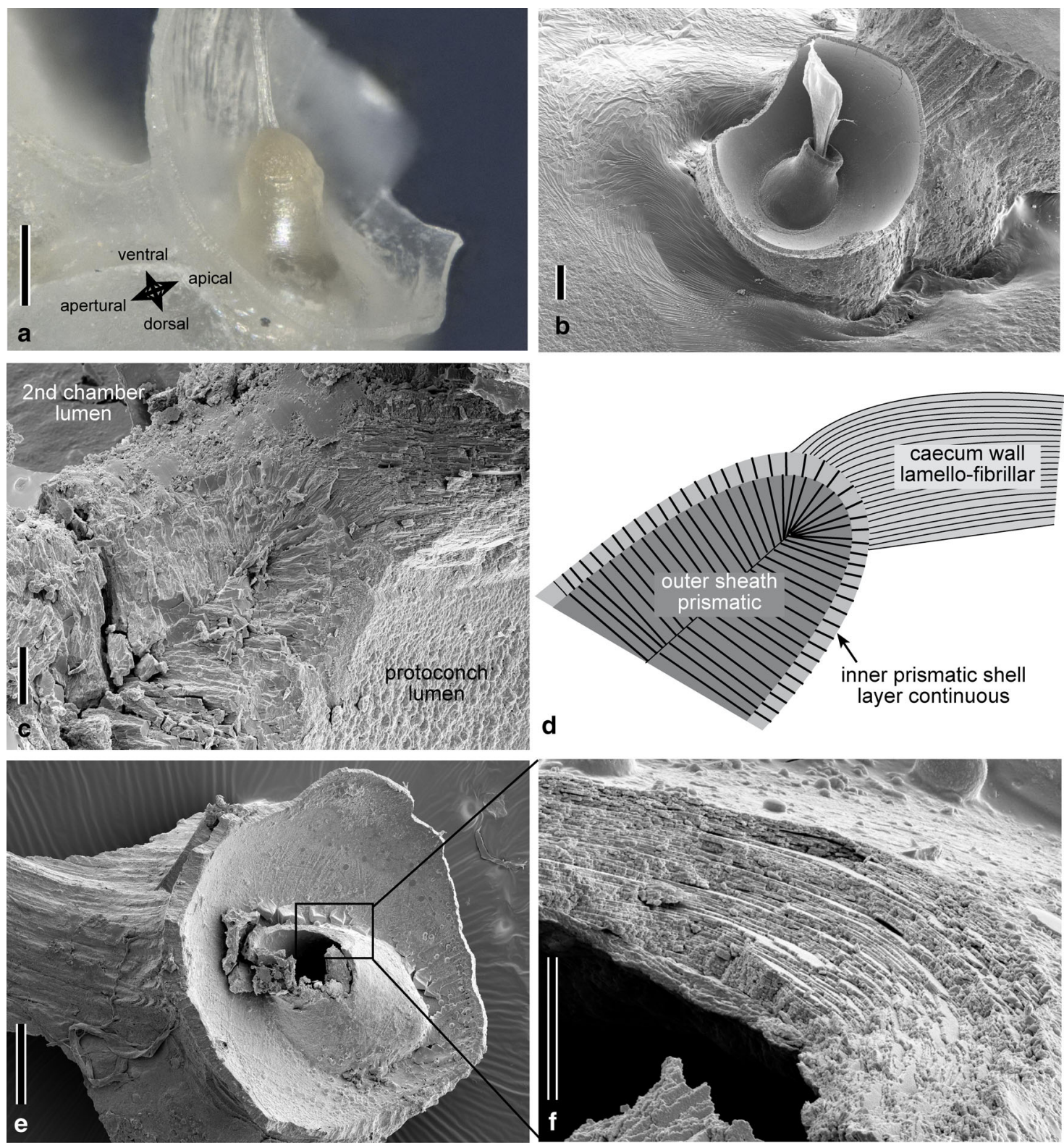

Fig. 3 The caecum of Spirula spirula, Spirulidae, recent, Mozambique. a Lateral overview of the opened protoconch showing the caecum and prosiphon; scale bar $=100 \mu \mathrm{m}$. b SEM image of the opened protoconch in apical view showing the caecum and prosiphon; scale bar $=100 \mu \mathrm{m}$. c SEM image showing a cross fracture of the protoconch/teleoconch transition (dorsal part); scale bar $10 \mu \mathrm{m}$.

d Camera lucida of protoconch/teleoconch transition reflecting the interactions between lamello-fibrillar caecum, inner protoconch layer, and outer sheath. e SEM image showing fractured caecum; scale bar $=100 \mu \mathrm{m}$. f Details of e showing the lamello-fibrillar ultrastructure of the caecum wall; scale bar $=10 \mu \mathrm{m}$

organic prosiphon (e.g. Zakharov 1972; Drushchits et al. 1977; Landman and Bandel 1985; Kulicki et al. 2015; De Baets et al. 2015). Bandel (1989: p. 69) noted a widely neglected difference between the ammonoid and spirulid caecum: "The lateral parts of the attachment between the caecum and the first septum represents a narrow, porous zone. The fluid exchange probably occurred through this zone; and not through the cap of caecum as in Recent Spirula."

Orthoceratida. Workers widely accept the presence of an organic caecum and the absence of a prosiphon (e.g. Stenzel in Sweet 1964; Erben et al. 1969; Ristedt 1971; Blind 1987).

Nautilida. Authors as Stenzel in Sweet (1964), Arnold et al. (1987) or Tanabe and Uchiyama (1997) have reported on a 'caecum' in Nautilus (Fig. 4d). Unlike other cephalopods, the Nautilus type of caecum cannot penetrate the first septum as it lacks a siphuncular foramen. 

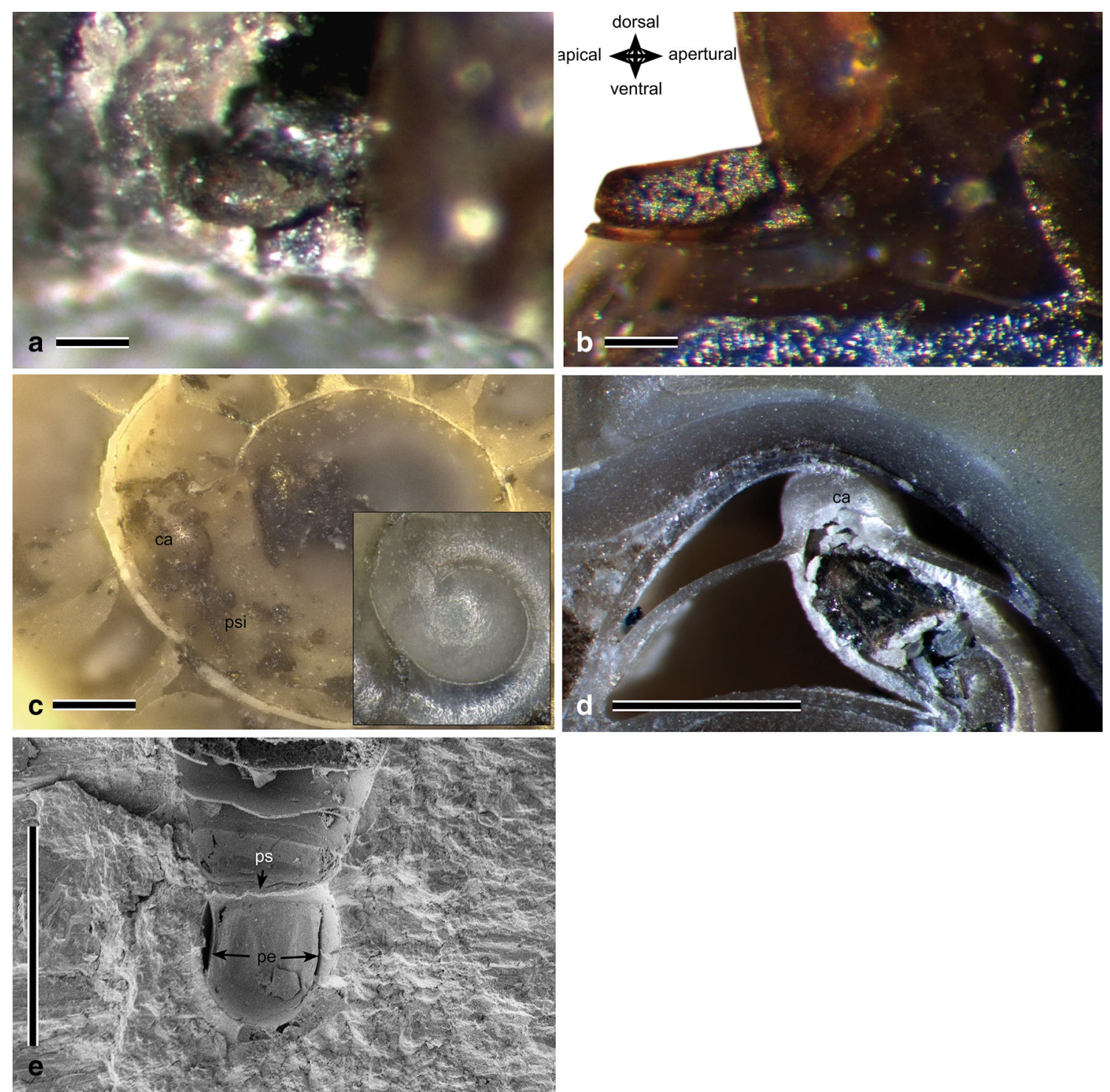

Fig. 4 The caecum of Cyrtobelus hornbyense, Groenlandibelidae, Upper Cretaceous (upper Campanian), Canada. a Apical view of the open protoconch showing the caecum; scale bar $=10 \mu \mathrm{m}$. b Longitudinal section of the protoconch/teleoconch transition showing the caecum in lateral view; scale bar $=10 \mu \mathrm{m}$. The caeca (ca) of an ammonoid, Upper Cretaceous, Hkkaido, Japan (c) and Nautilus,

\section{Closing membrane ('membrana tactiva')}

The closing membrane is an organic, septum-like membrane that (where known) completely seals the protoconch of belemnoid coleoids (Fig. 4e). It is adapically convex and attached to the waist-like apertural rim of the protoconch wall. The blind end of the siphuncular tube attaches to the prochoanitic septal necks of the first mineralized septum (Bandel et al. 1984; Doguzhaeva et al. 2014; Doguzhaeva $\&$ Melendez 2017); i.e. the siphuncle does not enter the lumen of the protoconch. The space between the closing membrane and the first septum proper is usually very

recent (d); scale bars: $\mathrm{d}=1 \mathrm{~mm}$; $\mathrm{c}=100 \mu \mathrm{m}$. e The caecum-less protoconch of Holcobelus munieri, Belemnitida, Middle Jurassic, NW France. Note a closing membrane is absent, although the likewise organic pellicula ("protoconch pockets" after Doguzhaeva et al. 2014) is preserved; $p e$ Pellicula, $p s$ proseptum; scale bar $=500 \mu \mathrm{m}$

narrow. It is therefore not considered to represent a true 'chamber'.

Naef (1922) surprisingly avoided discussing the detailed protoconch morphology of belemnoids, although Granjean (1910: p. 514, Fig. 17) had already recognized that in Belemnitida, the siphuncle does not enter the lumen of the protoconch due to a septum-like membrane. Nobody discussed the origin of the closing membrane in greater detail than Jeletzky (1966: p. 125/126). However, the value of his observations and interpretations on protoconchs is hampered by limited magnifications. For instance, the ultrastructure of the coleoid septa could not be determined and 
the fact that the protoconch wall peters out in belemnoids is also not visible under low magnifications. His idea of the morphogenetic origin of the closing membrane additionally appears somewhat confusing. He mentioned that the membrane represents a rudimentary caecum, although he assumed the membrane to be an outgrowth of the pellicula that lines the inner surface of the protoconch. Is the 'closing membrane' nothing else than a part of the pellicula? As a third option, he hypothesized that the closing membrane "...of the Belemnitida evolved from the first proseptum of their ectocochlian ancestors....The caecum probably diminished gradually by becoming more and more shallow in these ancestors until disappeared altogether.....".

The observation of a closing membrane in Diplobelida (Drushchits et al. 1984) and Aulacoceratida (Bandel 1985) led many authors to consider the closing membrane as an autapomorphy of the 'Belemnoidea' (Berthold and Engeser 1987; Engeser and Bandel 1988; Engeser 1990; Haas 1997, 2003; Fuchs 2006). However, the latter view has recently been challenged by the discoveries of the oldest known coleoid protoconchs (Doguzhaeva 2002; Doguzhaeva et al. 2003a; Mapes et al. 2010), since there is no evidence of a closing membrane in these Carboniferous belemnoid-like coleoids. Also, Fuchs et al. (2012b) could not confirm a closing membrane in the diplobelid Conoteuthis. Doguzhaeva et al. (2014) finally revealed further inconsistencies in the morphology of the belemnoid closing membrane. According to the latter publication, Belemnitida can either possess a typical closing membrane, lack the same, or can exhibit a closing membrane with a distinct foramen.

To my knowledge, currently only one report of a closing membrane outside belemnoids has been made by Mapes (1979) in bactritoids. He assumed a closing membrane in Late Carboniferous Bactrites woodi, because the protoconch is completely sealed; i.e. the 'closure' lacked a septal foramen.

\section{Protoconch wall}

While previous studies have mainly focused on the texture of the protoconch wall, only a few workers have paid attention on the course of the layer(s) at the junction between protoconch and the second chamber.

Belemnoid coleoids. With respect to Belemnitida, Müller-Stoll (1936) thought that the protoconch wall (his $s$ tratum callosum) continues as the conotheca into the next chamber. Jeletzky (1966: p. 125), who correctly recognized that Müller-Stoll's stratum callosum corresponds to the primordial rostrum rather than to the conotheca proper, observed a two-layered protoconch wall, which "persists across the protoconch's "waist" and merges respectively into the inner and outer layers of the conotheca." This microscope-based interpretation could not withstand ultrastructural SEM analyses. Bandel et al. (1984) were the first to detect a unilayered and discontinuous protoconch wall and also Doguzhaeva et al. (1999, 2003b, 2014) as well as Doguzhaeva \& Melendez (2017) repeatedly documented that the protoconch wall wedges out near the constricted aperture of the protoconch.

A similar tapering of the protoconch wall has been described in Triassic aulacoceratids (Bandel 1985) and Carboniferous aulacoceratid-like belemnoids (Doguzhaeva et al. 2003a, 2006, 2014). By contrast, Mapes et al. (2010: Fig. 2) indicated (either intentional or not?) in their diagram a continuous wall in early Carboniferous Hematites. Based only on light microscope investigations, diplobelids have been assumed to possess either a continuous (Drushchits et al. 1984) or a discontinuous protoconch wall (Fuchs et al. 2012b).

Spirulid and sepiid coleoids. Despite abundant material, only very few specifications have been made on the continuity of the prismatic wall of Sepia and Spirula. However, opinions are largely congruent that the spirulid/sepiid prismatic wall is unilayered and continuous (Mutvei 1964; Fuchs 2006). Jeletzky (1966) and recently Fuchs et al. (2012a) found the same condition in the Late Cretaceous spirulid Cyrtobelus.

Bactritida. The ultrastructural knowledge about the bactritoid protoconch wall is strongly limited. According to Doguzhaeva (2002: p. 11), the protoconch wall appears three layered; the two innermost layers peter out near the first septum, while the outer layer is continuous.

Ammonoidea. Studies on the course of embryonic shell layers are largely restricted to Mesozoic ammonoids owing to the scarcity of unaltered Palaeozoic material. Interestingly, the distribution of shell layers at the end of the protoconch was subject to a long debate (see De Baets et al. 2015 for a summary). However, in their most recent reviews on the structure of the ammonitella shell wall, authorities such as Tanabe et al. (2008: Fig. 11, Kulicki et al. (2015: Fig. 8.1) and De Baets et al. (2015: p. 166) have agreed that of the three protoconch wall layers the outer and middle layers are continuous, while the inner prismatic layer wedges out and there is no reason to assume that Palaeozoic ammonoids significantly differ from the latter construction (Kulicki et al. 2002). Nevertheless, details of protoconch morphology in the most primitive ammonoids are still unknown because no ammonoids in aragonitic preservation are known from the Devonian yet.

Orthoceratida/Nautilida. According to Ristedt (1971) and Erben et al. (1969), the wall of the apex peters out in Orthoceratida. In Nautilus, observations are congruent with regard to a discontinuous initial shell wall (Arnold et al. 1987). 


\section{First mineralized septum (proseptum, protoseptum)}

Spirulid and sepiid coleoids. Mutvei (1964: p. 271) noted about Spirula that the first mineralized septum has been "completely replaced" by the deep apertural constriction of the protoconch except its septal neck and the corresponding parts of the connecting ring. Bandel and Boletzky 1979: p. 320) believed in the absence of a first mineralized septum, and they remarked that the calcified portion of the caecum is constructed in the same way as the later septa. On the basis of its position and lamello-fibrillar texture, Dauphin, (1976) and Fuchs (2006: p. 12) concluded that the lateral caecum wall, which attaches the strongly constricted shell wall, represents the remains of the first mineralized septum.

Regarding the conditions of fossil spirulids, Jeletzky (1966: p. 103) only remarked that the "first septum of G. rosenkrantzi [= Cyrtobelus birkelundae] differs from the closing membrane of Aulacocerida and Belemnitida only in having a septal foramen and septal neck. Its mural part is too poorly preserved, however, to determine whether it merges into the walls of the protoconch as the belemnitid closing membrane appears to do." According to Fuchs et al. (2012a), the first mineralized septum of Cyrtobelus is lamello-fibrillar in ultrastructure and attaches with comparatively short mural parts to the slightly constricted shell wall.

In recent Sepia, the first septum proper is-as in Cenozoic belosaepiids-lamello-fibrillar and attached to the inner prismatic layer of the conotheca (Bandel and Boletzky 1979; own observations).

Belemnoid coleoids. Due to the presence of an organic closing membrane, workers must clearly distinguish between the first organic (= closing membrane) and the subsequent (second) mineralized (= first after Bandel et al. 1984) septum. Jeletzky (1966) therefore homologized the first mineralized septum in belemnitids and the second septum of ammonoids. Bandel et al. (1984) observed in belemnitid Hibolithes a first mineralized septum that is prismatic in ultrastructure, which possesses prochoanitic septal necks, and whose long mural parts attaches the prismatic shell wall. Doguzhaeva et al. (2003b: p. 85), by contrast, observed a prismatic first septum that "...continues in the apertural direction forming the prismatic inner layer of the conotheca.....the inner layer of the phragmocone wall is formed by a continuation of the mural part of the first septum."

In aulacoceratid belemnoids, Bandel (1985) observed a prismatic first septum that inserts into the conotheca. In the Carboniferous aulacoceratid-like Mutveiconites, Doguzhaeva et al. (2006), by contrast, found a continuous first septum identical to the construction in belemnitids. Own material of Aulacoceras displays a continuous first septum rather than a continuous protoconch wall. In diplobelids, Drushchits et al. (1984) regarded the first septum to be attached to the conotheca, whereas Fuchs et al. (2012b) assumed the first mineralized septum to continue as the inner prismatic layer of the conotheca.

Bactritida. According to Doguzhaeva (2002: p. 12), the first mineralized septum is prismatic and has mural parts as long as the second chamber. In congruence with the presence of a caecum located in the lumen of the protoconch, the first septum is known to display a septal foramen (Doguzhaeva, 2002) with one exception. Mapes (1979: pl. 18, Fig. 8) figured a specimen of Bactrites woodi with an apparently unperforated first septum.

Ammonoidea. Most investigations on Mesozoic and Palaeozoic ammonoids are congruent with respect to the presence of a prismatic and perforated first (pro)septum (e.g. Erben et al. 1969; Kulicki 1975; Drushchits et al. 1977; Landman and Bandel 1985; Kulicki and Doguzhaeva 1994; Klofak et al. 1999; Kulicki et al. 2002, 2015; De Baets et al. 2015). The continuity of the mural parts of the proseptum (virtually unknown in the earliest ammonoids with an open umbilical window in, e.g. Anetoceratinae, Mimoceratidae, Mimagoniatitidae, Anarcestidae) is less well established. While some authors have suggested that the type of attachment of the proseptum would not differ from subsequent septa, others found significant differences (see Kulicki et al. 2015: p. 331). According to Drushchits et al. (1977), Kulicki (1979), Bandel (1982), Landman and Bandel (1985), and Kulicki et al. (2002, 2015), the proseptum continues dorsally and ventrally into the conotheca of the first whorl. Drushchits et al. (1977) and Landman and Bandel (1985) additionally noted that the second septum is dorsally attached to the proseptum.

Orthoceratoid cephalopods. The construction of the protoconch is overall generally consistent in the presence of a perforated and nacreous proseptum, which attaches the inner prismatic layer of the conotheca (e.g. Erben et al. 1969; Ristedt 1971; Doguzhaeva 2002).

Nautilida. In Nautilus, the terminology of the first mineralized septum slightly deviates from those of other cephalopods. It is called 'protoseptum', although it structurally composes the shell wall rather than the division of two chambers. "It should be emphasized that the protoseptum is a secondary deposit at the interior of the apical region of the embryonic shell and not a true septum that delineates a chamber. In other words, it forms the apical surface of the first chamber and is not penetrated by the siphuncle" (Arnold et al. 1987: p. 382). The protoseptum is composed of a well-developed nacreous layer between the inner and outer prismatic layers and shows no evidence of a siphuncular foramen. The comparatively low protoconch is hence sealed by the second mineralized septum, which is likewise composed of tabular nacre. 


\section{Discussion}

The review above shows that the morphogenetic origin of protoconch substructures such as the spirulid caecum can only be understood when examined in their general context of related cephalopod groups. Among phragmocone-bearing coleoids, belemnoid, sepiid and the spirulid main types of protoconchs can be distinguished more or less clearly (compare Reitner and Engeser 1982). Although the protoconch of Sepia is strongly modified (shield shaped rather than egg shaped) and devoid of a caecum, its sub-elements (protoconch wall continuous, 1st septum lamello-fibrillar) are ultrastructurally identical to the spirulid type. The sepiid type can therefore feasibly be derived from the spirulid type (Figs. 5, 6).

Derivation of the spirulid type from either the ammonoid (Fig. 5) or belemnoid type (Fig. 6) is by contrast less simple owing to fundamental differences in architecture and ultrastructure. As outlined above, the spirulid protoconch has traditionally been interpreted to be closer to the ammonoid protoconch-mainly based on the shared presence of a 'caecum' in the lumen of the protoconch (Fig. 5). However, a detailed comparison shows that the belemnoid type is also very similar to the ammonoid type (Fig. 6).

How was the protoconch of the first coleoid built? Based on the structural similarities of the bactritoid and ammonoid protoconchs, the coleoid archetype can be reconstructed as being enveloped from outside (due to the internalization of the shell; see Fuchs 2012) by a secondary shell layer and separated from the teleoconch through a sharp growth interruption (Figs. 5, 6). The mural parts of the prismatic (first mineralized) proseptum were continuous and became the conotheca proper; the perforated proseptum accordingly represented the backside of the teleoconch. The coleoid shell archetype possessed lamellofibrillar septa from the second septum onward. The location of the first siphuncular segment and the way how the protoconch was completely sealed remain ambiguous (Figs. 5, 6). This organization of the coleoid protoconch archetype can be found in the Late Carboniferous Mutveiconites (Doguzhaeva et al. 2006). As in Mutveiconites, the protoconch of the Early Carboniferous Hematites is missing evidence of either a caecum or a closing membrane (Mapes et al. 2010). Hence, in ammonoids, bactritoids, early coleoids, and Mesozoic belemnoids, the apertural growth of the protoconch commonly stopped and the backside of the newly formed teleoconch closed the protoconch except for a small foramen. In spirulids and sepiids, by contrast, the protoconch wall continues as the future conotheca and the 'first septum' represents a true septum in being lamellofibrillar in ultrastructure and attached to the conotheca. Two main scenarios are conceivable for the morphogenetic origin of the spirulid/sepiid type of protoconch.

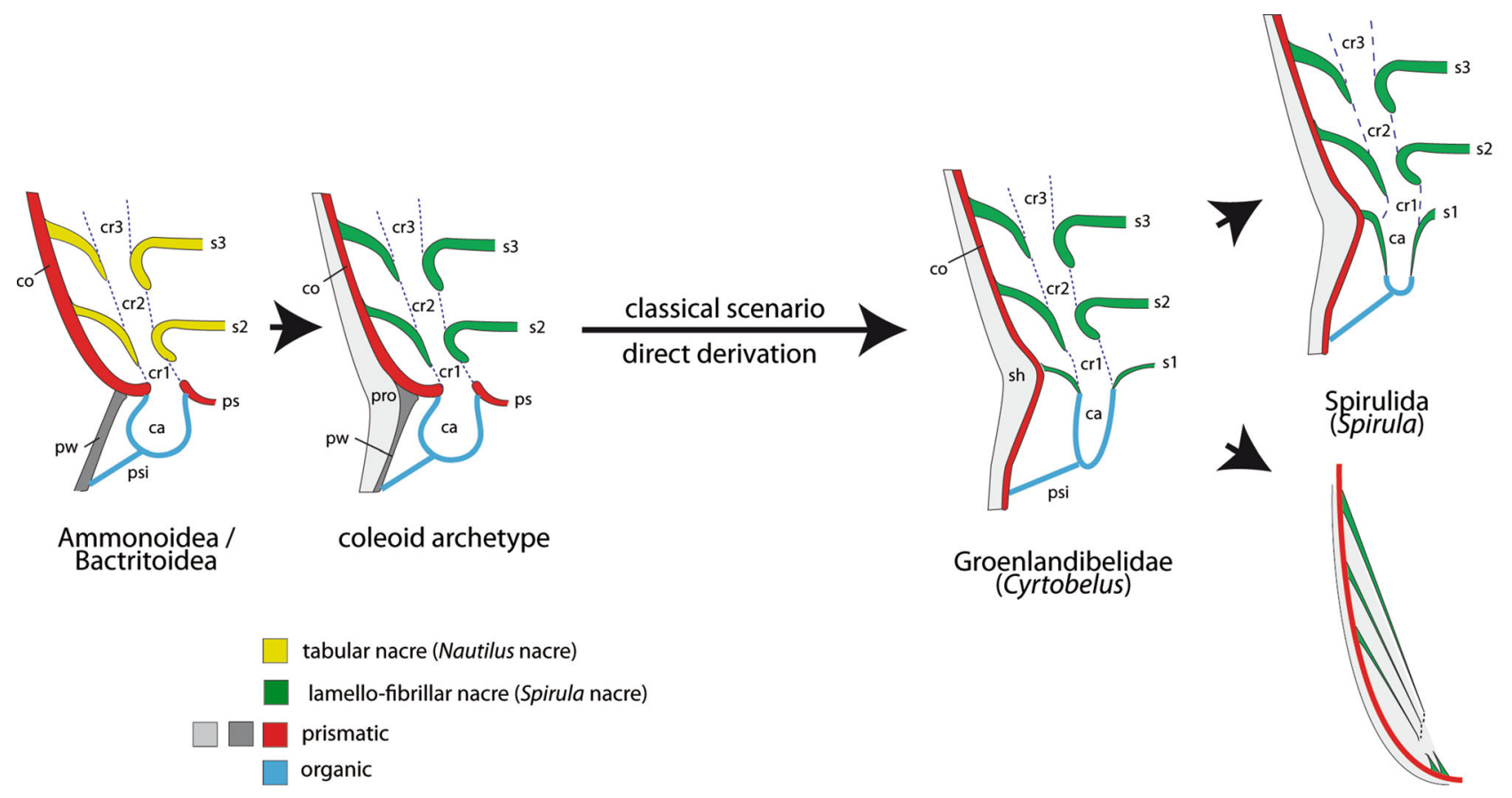

Sepiida (Sepia)

Fig. 5 The classical evolutionary scenario (scenario 1) implicating a direct derivation of the spirulid from the ammonoid caecum. Focus is made on the ventral shell part. ca caecum, co conotheca, crl-3 connecting rings $1-3$, pro primordial rostrum, $p w$ protoconch wall, $p s$ proseptum, psi prosiphon, s1-3 septa 1-3, sh sheath 


\section{Scenario 1 ('classical scenario'): morphogenetic origin of the spirulid/sepiid type of protoconch from the ammonoid type (Fig. 5)}

Prerequisite for this 'classical scenario' is an organic caecum that enters the lumen of the protocoleoid protoconch. This caecum is apically attached to the prismatic protoconch wall via the prosiphon. To directly derive the spirulid protoconch, it was necessary to abandon the protoconch/teleoconch separation present in ammonoids and bactritoids. This modification from a discontinuous to a continuous shell wall is not complicated with respect to the shell wall secreting epithelium, but affords the re-organization of the epithelium forming the first septum (septal epithelium), which does not represent the backside of the teleoconch anymore. In ammonoids (and in the earliest coleoids probably as well), the first septum (proseptum) is prismatic and must have been secreted by the shell wall

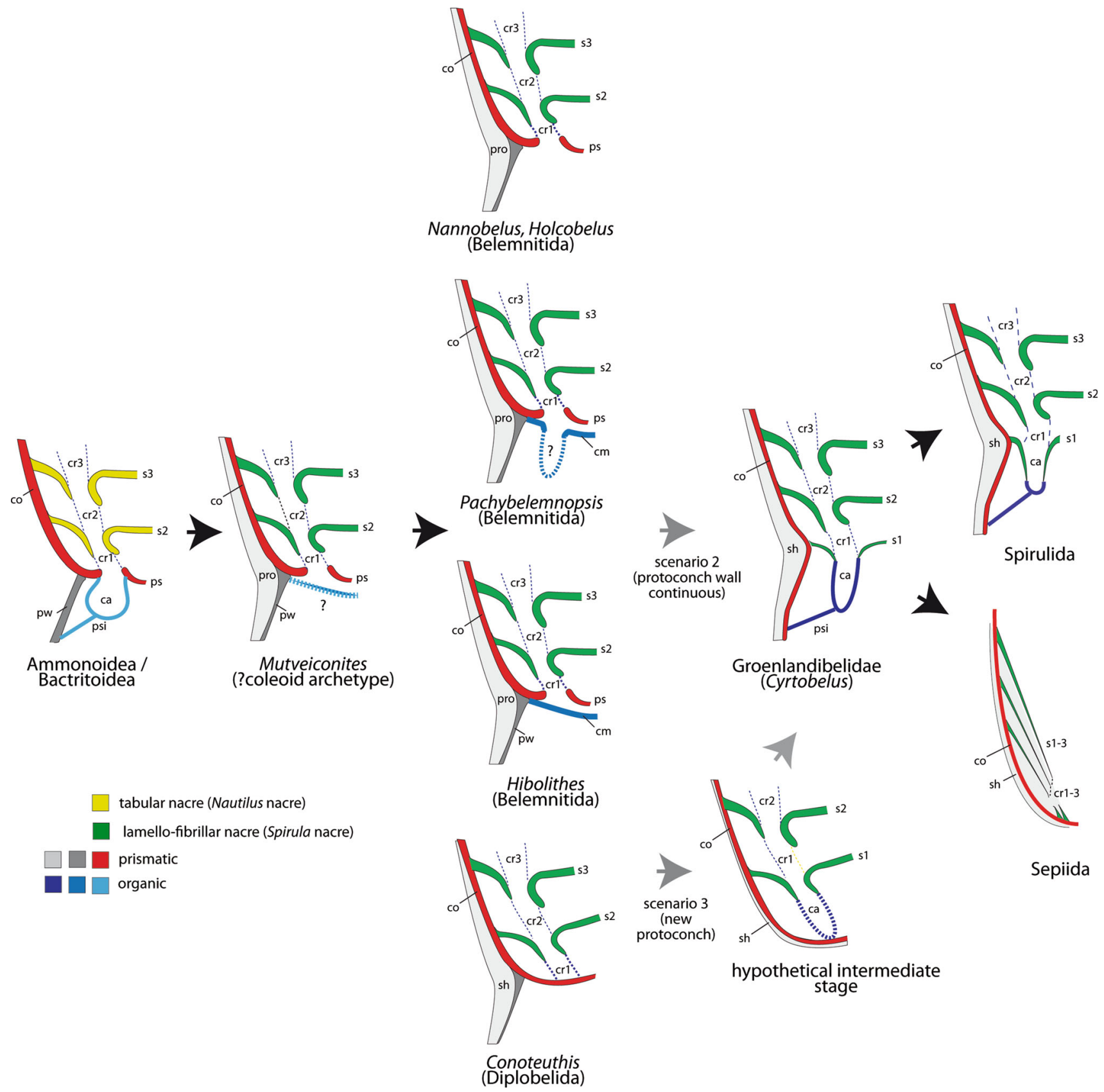

Fig. 6 Multiple step scenarios (scenarios 2-3) implicating derivation of the spirulid protoconch from belemnoid subtypes. Focus is made on the ventral shell part. Note the belemnitid rostrum proper is a post- embryonic formation and therefore not indicated here. Abbreviations as in Fig. 5: $\mathrm{cm}$ closing membrane 
secreting mantle epithelium, whereas in spirulids/sepiids, the first septum is secreted by the posterior septal epithelium.

\section{Scenarios 2-3 (multiple steps scenarios): morphogenetic origin of the spirulid/sepiid type of protoconch from the belemnoid type (Fig. 6)}

The following scenarios result from the phylogenetic trees obtained by Fuchs et al. (2013), Fuchs \& Iba (2015), Sutton et al. (2015) and Klug et al. (2016), which have exposed belemnitids and diplobelids as stem decabrachians. Derivation from the caecum-less belemnoid protoconch type implicates the initial loss and the later re-appearance of the combined presence of a 'caecum' and prosiphon in the evolutionary history of the Coleoidea. Owing to the existence of different belemnoid protoconch subtypes, it is difficult to reconstruct their ancestral protoconch morphology. The presence of an unperforated closing membrane (aulacoceratids where known, most belemnitids (?) diplobelid Tauriconites) is the most common condition. The presence of a perforated closing membrane (e.g. in the belemnitid Pachybelemnopsis) and the total absence of a closing membrane (belemnitid Nannobelus) are ostensibly unusual (see Doguzhaeva et al. 2014). The absence of a closing membrane combined with a prismatic proseptum missing a septal foramen-as in the diplobelid Conoteuthis-is likewise exceptional.

A pathway via the belemnoid protoconch requires-as in the classical scenario 1-the loss of the protoconch/ teleoconch separation ( $=$ a shift from a discontinuous to a continuous protoconch wall), which early belemnoids (e.g. Mutveiconites) inherited from their bactritoid ancestors. A re-organization of secreting epithelia is hence likewise obligatory in this scenario. It appears plausible to assume that the closing membrane simply detached from the protoconch aperture and re-attached to the lamello-fibrillar septal necks of the first septum (scenario 2 in Fig. 6). This pathway would conform with Jeletzky's hypothesis, whereupon the closing membrane is "...possibly representing the rudimentary caecum of ectocochlian ancestors..." (Jeletzky 1966: p. 125).

However, in the light of the variety of belemnoid subtypes, alternative evolutionary pathways are possible. A derivation of the spirulid protoconch from the diplobelid subtype is an attractive hypothesis, particularly as Hewitt and Jagt (1999) as well as Fuchs et al. (2013) regarded the Diplobelida as the root stock of the Decabrachia (scenario 3 in Fig. 6). The total closure of the Conoteuthis protoconch without any permeable membrane is a drastic development for the embryo, certainly leading to a dysfunctional buoyancy device. Taking this background into account, it is highly interesting that the arrangement of protoconch elements in Spirula and Cyrtobelus is identical to that in the second chamber of Conoteuthis. The initial wall was continuous, the associated septum lamello-fibrillar, and the organic connecting ring connected chamber wall and septum. In other words, scenario 3 suggests that the decabrachian protoconch is not homologous with that of belemnoids and other ectocochleate cephalopods. This approach may appear surprising, but would be congruent with Bandel et al. (1984: p. 300), who remarked: "One can absolutely interpret a caecum in the second septum, where the siphuncular tube ends blindly and where prosiphoequivalent fixing lamella exist, which do indeed not enter the initial chamber, but end on its closure." This idea implies that the first spirulid/sepiid septum is equivalent to the second belemnoid septum and the caecum (and prosiphon) homologous to the first connecting ring in belemnoids.

Such a pathway requires that the earliest crown decabrachians got rid of the dysfunctional diplobelid protoconch (?ontogenetic abbreviation) and developed a protoconch of spiruloid type with a caecum. In this context, Boletzky (1993: p. 35) stated: "Most shell modifications can be interpreted as a result of heterochronic shifts between localized production "programs" of the shell gland complex." Abandonment of the protoconch, i.e. the earlier onset of teleoconch formation, points to a peramorphic (predisplacement) growth. Fuchs (2012: p. 60) previously reported neotenic growth traits in the Cenozoic evolution of spirulids (Late Cretaceous Cyrtobelus, Palaeocene-Eocene Belopterina, Oligocene Spirulirostra, Miocene Spirulirostrina, Spirula). In this evolutionary series, individuals progressively retain more early ontogenetic features such as coiling and the delayed secretion of the thickened part of the sheath.

\section{Phylogenetic-systematic implications}

According to Jeletzky (1966: p. 80) “... neither the abovementioned early workers nor later ones......realized that the known or inferred presence of a caecum and prosiphon in Spirula and other Recent and fossil sepiids (....) is incompatible with their generally assumed derivation from the Belemnitida." This attitude is not beyond any doubt as most recent phylogenetic analyses show (Figs. 2b, 6, 7). The review above, moreover, suggests various plausible alternative pathways for the morphogenetic derivation of the spiruloid from the belemnoid type of protoconch and thus an independent evolution of the spiruloid type of caecum. Accordingly, the spiruloid protoconch and hence the spiruloid caecum evolved during the Early Cretaceous. Key taxon in this discussion represents Longibelus, a genus typified by a mosaic of diplobelid and groenlandibelid characters (Fuchs et al. 2013). Perspectively, the detailed 

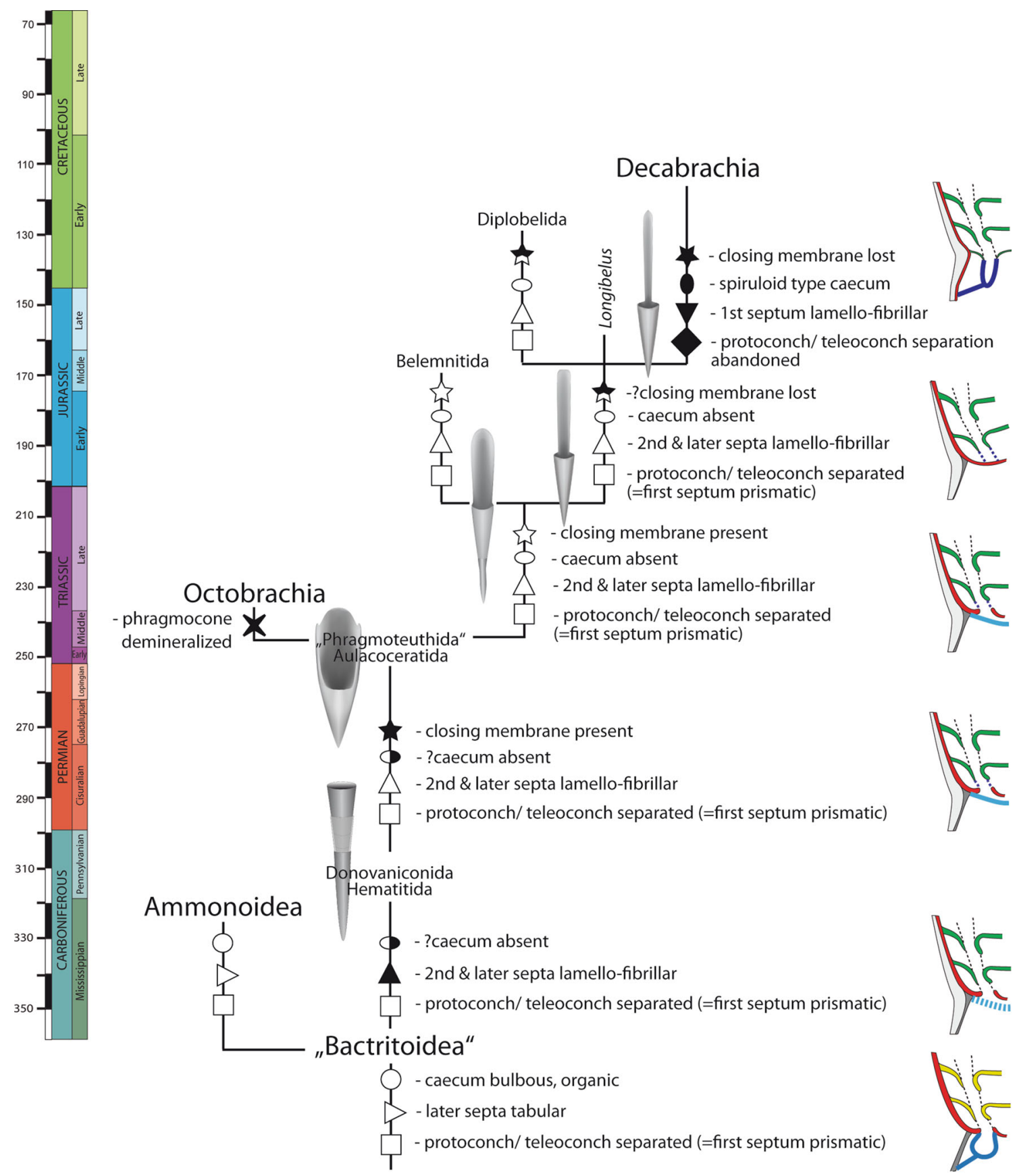

apomorphic

$\hat{\imath}$ plesiomorphic

Fig. 7 Phylogenetic tree of the Coleoidea with focus on protoconchrelevant characters and their evolutionary transformations (tree topology based on Fuchs et al. 2013; Klug et al. 2016; Sutton et al.

protoconch morphology of Longibelus will provide new insights into the origin of the decabrachian type of protoconch and allow to test existing hypotheses on the homology of the Spirula caecum. Considering the Spirula caecum as an autapomorphy of crown decabrachians polarization uncertain

2015). The spirulid caecum accordingly evolved de novo (instead of directly from their bactritoid ancestors)

(rather than a plesiomorphy inherited from ectocochleate ancestors) is in agreement with the most recent divergence estimates of the Coleoidea (Tanner et al. 2017) and deprives an important argument supporting the idea of a Palaeozoic origin of decabrachian crown groups. 


\section{Spirula as a model for developmental inferences?}

Nautilus is known to be a poor model for the reconstruction of ammonoid life strategies. Spirula has been considered to represent a better model, particularly with respect to the embryonic development (e.g. Warnke and Keupp 2005). However, as outlined above, the formation of the Spirula protoconch runs fundamentally different compared to the ammonoid protoconch. In this context, it is essential to emphasize that the genus Spirula evolved during the Miocene from cyrtoconic spirulirostrid ancestors with an irregularly thickened guard-like sheath. Hence, Spirula cannot be seen as a 'living fossil', and thus, using Spirula for palaeobiological inferences is problematic.

\section{Conclusions}

1. The bactritoid/ammonoid type of caecum differs strikingly from the Spirula type of caecum. The caecum of Spirula consists of lamello-fibrillar nacre and can therefore be homologized with the rudimentary first septum; only the cap-like membrane sealing the caecum apex is organic. By contrast, the bulbous caecum is completely organic and attached to the septal necks of the prismatic proseptum in ammonoids.

2. In general, the bactritoid/ammonoid and spiruloid types of protoconchs are architecturally different. With respect to a protoconch/teleoconch separation and the presence of a prismatic proseptum, the bactritoid/ ammonoid type of protoconch is structurally closer to the belemnoid than to the spiruloid type.

3. The most fundamental step in the re-organization of the spiruloid type of protoconch, namely the loss of the protoconch/teleoconch separation, must have occurred in the classical bactritoid scenario 1 as well as the belemnoid scenarios $2-3$. The loss of the protoconch/ teleoconch separation, which is equivalent to the substitution of the epithelium that secretes the first septum, is certainly more complicated than modifications (outgrowths, dislocation, re-attachment) of non-mineralized structures such as the closing membrane and the caecum.

4. Although more comparative SEM studies on the protoconch morphologies of various cephalopod groups are necessary, in view of the fact that the belemnoid second chamber and the spiruloid/sepiid protoconch are structurally identical, it is possible that the last common ancestor of the Decabrachia relinquished to build a true protoconch and instead immediately started with the formation of the teleoconch.
5. Numerous arguments against the presumed homology between the ectocochleate and spiruloid caecum have been presented. Therefore, I consider these caeca as not being homologous.

Acknowledgements I greatly appreciate the help of René Hoffmann and Christian Klug, whose thorough reviews significantly improved the manuscript.

\section{References}

Arnold, J. M., Landman, N. H., \& Mutvei, H. (1987). Develoment of the Embryonic Shell of Nautilus. In W. B. Sanders \& N. H. Landman (Eds.), Nautilus: The Biology and Paleobiology of Living Fossil. New York: Plenum Press.

Bandel, K. (1985). Composition and ontogeny of Dictyoconites (Aulacocerida, Cephalopoda). Paläontologische Zeitschrift, 59(3/4), 223-244.

Bandel, K. (1989). Cephalopod shell Structure and General Mechanisms of Shell Formation. In J. G. Carter (Ed.), Skeleton Biomineralization: Patterns, Processes and Evolutionary Trends (Vol. 1, pp. 97-115). New York: Van Nostrand Reinhold.

Bandel, K., \& Boletzky, S. V. (1979). A comparative study of the structure, development and morphological relationships of chambered cephalopod shells. The Veliger, 21, 313-354.

Bandel, K. (1982). Morphologie und Bildung der frühontogenetischen Gehäuse bei conchiferen Mollusken. Facies, 7, 1-198.

Bandel, K., Engeser, T., \& Reitner, J. (1984). Die Embryonalentwicklung von Hibolithes (Belemnitida, Cephalopoda). Neues Jahrbuch für Geologie und Paläontologie Abhandlungen, 167, 275-303.

Barskov, I. S. (1982). On the evolution of cephalopod ontogeny. In V. V. Menner \& V. V. Druzschic (Eds.), Morphogenesis and Development Paths of Fossil Invertebrates (pp. 61-79). Moscow: Moscow State University.

Berthold, T., \& Engeser, T. (1987). Phylogenetic analysis and systematization of the Cephalopoda (Mollusca). Verhandlungen des Naturwissenschaftlichen Vereins Hamburg, 29, 187-220.

Blind, W. (1987). Vergleichend morphologische und schalenstrukturelle Untersuchungen an Gehäusen von Nautilus pompilus, Orthoceras sp., Pseudorthoceras sp. und Kionoceras sp. Palaeontographica A, 198(4-6), 101-128.

Boletzky, S. V. (1992). Evolutionary aspects of development, life style, and reproduction mode in incirrate octopods (Mollusca, Cephalopoda). Revue de Suisse Zoologie, 4, 755-770.

Boletzky, S. V. (1993). Developmental and reproduction in the evolutionary biology of Cephalopoda. Geobios, Memoire Special, 15, 33-38.

Dauphin, Y. (1976). Microstructure des coquilles de Céphalopodes. I. Spirula spirula L. Bulletin du muséum national d'histoire naturelle, 3(382), 199-238.

De Baets, K., Klug, C., Korn, D., \& Landman, N. H. (2012). Early evolutionary trends in ammonoid embryonic development. Evolution, 66(6), 1788-1806.

De Baets, K., Landman, N. H., \& Tanabe, K. (2015). Ammonoid Embryonic Development. In C. Klug, D. Korn, K. De Baets, I. Kruta, \& R. H. Mapes (Eds.), Ammonoid Paleobiology: From Anatomy to Ecology (Vol. Topics in Geobiology 43, pp. 113-205). Dordrecht: Springer.

Doguzhaeva, L. A. (2002). Adolescent Bactritoid, Orthocerid, Ammonoid and Coleoid Shells from the Upper Carboniferous 
and Lower Permian of the South Urals. Abhandlungen der geologischen Bundesanstalt, 57, 9-55.

Doguzhaeva, L. A., Mapes, R. H., \& Dunca, E. (2006). A Late Carboniferous adolescent cephalopod from Texas (USA), with short rostrum and a long body chamber. Acta Universitatis Carolinae - Geologica, 49, 55-68.

Doguzhaeva, L. A., Mapes, R. H., \& Mutvei, H. (2003a). The shell and inc sac Morphology and Ultrastructure of the Late Pennsylvanian Cephalopod Donovaniconus and its phylogenetic significance. Berliner Paläobiologische Abhandlungen, 3, 61-78.

Doguzhaeva, L. A., \& Melendez, G. (2017). The embryonic conch structure as a supposed imperative factor on the hatchling dispersal and geographical expansion of belemnites: an example of Callovian (Middle Jurassic) pachybelemnopseins from Aragón (NE Spain). Neues Jahrbuch für Geologie und Paläontologie - Abhandlungen, 283(3), 317-334.

Doguzhaeva, L. A., Mutvei, H., Kabanov, G. K., \& Donovan, D. T. (1999). Conch ultrastructure and septal neck ontogeny of the belemnid Conobelus (Duvaliidae) from the Valangian of the Crimea (Black Sea). In F. Oloriz \& F. J. Rodriguez-Tovar (Eds.), Advancing Research on Living and Fossil Cephalopds (pp. 223-232). New York: Kluwer Academic/Plenum Publisher.

Doguzhaeva, L. A., Mutvei, H., \& Weitschat, W. (2003b). The proostracum and primordial rostrum at early Ontogeny of Jurassic Belemnites from North-Western Germany. Berliner Paläobiologische Abhandlungen, 3, 79-89.

Doguzhaeva, L. A., Weis, R., Delsate, D., \& Mariotti, N. (2014). Embryonic shell structure of Early-Middle Jurassic belemnites, and its significance for belemnite expansion and diversification in the Jurassic. Lethaia, 47, 49-65.

Donovan, D. T. (1977). Evolution of the dibranchiate Cephalopoda. Symposia of the Zoological Society of London, 38, 15-48.

Doyle, P., Donovan, D. T., \& Nixon, M. (1994). Phylogeny and systematics of the Coleoidea. The University of Kansas Paleontological Contributions (New Series), 5, 1-15.

Drushchits, V. V., Doguzhaeva, L. A., \& Mikhaylova, I. A. (1977). The structure of the ammonitella and the direct development of ammonites. Paleontological Journal (Translation of the Paleontologicheskiy Zhurnal), 1977(2), 57-69.

Drushchits, V. V., Kabanov, G. K., \& Nerodenko, V. M. (1984). Structure of the Phragmocone and Rostrum in Tauriconites gen. nov. (Coleoidea, Diplobelidae). Paleontological Journal (Translation of the Paleontologicheskiy Zhurnal), 1, 12-18.

Engeser, T. (1990). Major events in cephalopod evolution. In P. D. T. G. P. Larwood (Ed.), Major Evolutionary Radiations, Systematics Association (Vol. 42, pp. 119-138). Oxford: Clarendon Press.

Engeser, T., \& Bandel, K. (1988). Phylogenetic Classification of Cephalopods. In J. Wiedmann \& J. Kullman (Eds.), Cephalopods-Present and Past (p. 105). Stuttgart: Schweizerbart'sche Verlagsbuchhandlung.

Erben, H. K., Flajs, G., \& Siehl, A. (1969). Die frühontogenetische Entwicklung der Schalenstruktur ektocochleater Cephalopoden. Palaeontographica A, 132, 1-54.

Fuchs, D. (2006). Fossil erhaltungsfähige Merkmalskomplexe der Coleoidea (Cephalopoda) und ihre phylogenetische Bedeutung. Berliner Paläobiologische Abhandlungen, 8, 1-115.

Fuchs, D. (2012). The "rostrum"-problem in coleoid terminologyan attempt to clarify inconsistences. Geobios, 45, 29-39.

Fuchs, D., Boletzky, S. V., \& Tischlinger, H. (2010). New evidence of functional suckers in belemnoid coleoids weakens support for the "Neocoleoidea" concept. Journal of Molluscan Studies, 76(4), 404-406.

Fuchs, D., \& Iba, Y. (2015). The gladiuses in coleoid cephalopods: homology, parallelism, or convergence? Swiss Journal of Palaeontology, 134, 187-197.
Fuchs, D., Iba, Y., Ifrim, C., Nishimura, T., Kennedy, J., Keupp, H., et al. (2013). Longibelus gen. nov., a new Cretaceous coleoid genus linking Belemnoidea and Decabrachia. Palaeontology, 56(5), 1081-1106.

Fuchs, D., Keupp, H., Trask, P., \& Tanabe, K. (2012a). Taxonomy, morphology and phylogeny of Late Cretaceous spirulid coleoids (Cephalopoda) from Greenland and Canada. Palaeontology, 55(2), 285-303.

Fuchs, D., Keupp, H., \& Wiese, F. (2012b). Protoconch morphology of Conoteuthis (Diplobelida, Coleoidea) and its implications on the presumed origin of the Sepiida. Cretaceous Research, 34, 200-207.

Granjean, F. (1910). Le siphon des ammonites et des belemnites. Société Géologique de France, Bulletin, 10(6), 496-519.

Haas, W. (1989). Suckers and arm hooks in Coleoidea (Cephalopoda, Mollusca) and their bearing for phylogenetic systematics. Abhandlungen des naturwissenschaftichen Vereins in Hamburg, 28, 165-185.

Haas, W. (1997). Der Ablauf der Entwicklungsgeschichte der Decabrachia (Cephalopoda, Coleoidea). Paleontographica. Abteilung A, 245, 63-81.

Haas, W. (2003). Trends in the evolution of the Decabrachia. Berliner Paläobiologische Abhandlungen, 3, 113-129.

Hewitt, R. A., \& Jagt, J. W. M. (1999). Maastrichtian Ceratisepia and Mesozoic cuttlebone homeomorphs. Acta Palaeontologica Polonica, 44(3), 305-326.

Hyatt, A. (1872). The fossil cephalopods of the Museum of Comparative Zoology. Bulletin of the Museum of Comparative Zoology at Harvard College., 3, 59-111.

Jeletzky, J. A. (1966). Comparative morphology, phylogeny and classification of fossil Coleoidea. Paleontological Contributions, University of Kansas, Mollusca, 7, 1-166.

Klofak, S. M., Landman, N. H., \& Mapes, R. H. (1999). Embryonic Development of Primitive Ammonoids and the Monophyly of the AMMONOIDEA. In F. Oloriz, \& F. J. Rodriquez-Tovar (Eds.), Advancing Research on Living and Fossil Cephalopods (pp. 23-42). New York: Kluwer Academic / Plenum Publishers.

Klug, C., Schweigert, G., Fuchs, D., Kruta, I., \& Tischlinger, H. (2016). Adaptations to squid-style high-speed swimming in Jurassic belemnitids. Biology Letters. https://doi.org/10.1098/ rsbl.2015.0877.

Kulicki, C. (1975). Structure and mode of origin of the ammonite proseptum. Acta Palaeontologica Polonica, 20(4).

Kulicki, C. (1979). The Ammonite shell: its structure development and biological significance. Palaeontologia Polonica, 39, 97-142.

Kulicki, C., \& Doguzhaeva, L. (1994). Development and calcification of the ammonitella shell. Acta Palaeontologica Polonica, 39, $17-44$.

Kulicki, C., Landman, N. H., Heaney, M. J., Mapes, R. H., \& Tanabe, K. (2002). Morphology of the Early Whorls of Goniatites from the Carboniferous Buckhorn Asphalt (Oklahoma) with Aragonitic Preservation. Abhandlungen der geologischen Bundesanstalt, 57, 205-224.

Kulicki, C., Tanabe, K., Landman, N. H., \& Kaim, A. (2015). Ammonoid Shell Microstructure. In C. Klug, D. Korn, K. De Baets, I. Kruta, \& R. H. Mapes (Eds.), Ammonoid Paleobiology: From Anatomy to Ecology (Vol. Topics in Geobiology 43). Dordrecht: Springer.

Landman, N. H., \& Bandel, K. (1985). Internal structures in the early whorls of Mesozoic ammonites. American Museum Novitates, $2823,1-21$.

Landman, N. H., Tanabe, K., \& Yasunari, S. (1996). Ammonoid embryonic development. In N. H. Landman (Ed.), Ammonoid Paleobiology (Vol. 13, p. 343). New York: Plenum Press. 
Lindgren, A., Pankey, M., Hochberg, F., \& Oakley, T. (2012). A multigene phylogeny of Cephalopoda supports convergent morphological evolution in association with multiple habitat shifts in the marine environment. BMC Evolutionary Biology, 12(1), 129.

Mapes, R. H. (1979). Carboniferous and Permian Bactritoidea (Cephalopoda) in North America. The University of Kansas paleontological contributions, Article, 64, 1-75.

Mapes, R. H., Doguzhaeva, L. A., Mutvei, H., Landman, N. H., \& Tanabe, K. (2010). The oldest known (Lower CarboniferousNamurian) protoconch of a rostrum-bearing coleoid (Cephalopoda) from Arkansas, USA: phylogenetic and paleobiologic implications. In D. Fuchs (Ed.), Proceedings of the 3rd International Symposium "Coleoid Cephalopods Through Time" (Vol. 59, pp. 114-125, Vol. Ferrantia).

Meyer, J.-C. (1989). Un nouveau Cephalopode Coleoide dans le Paleocene inferieur de Vigny. SAGA Information (Paris), 94, 365.

Meyer, J.-C. (1993). Un nouveau coleoide Sepioide Ceratisepia elongata nov. gen., nov. sp. du Paleocene inferieur (Danian) de Vigny. Implications taxonomiques et Phylogenetiques. Geobios, Memoire Special, 15, 287-304.

Müller-Stoll, H. (1936). Beiträge zur Anatomie der Belemnoidea. Nova Acta Leopoldina, 4, 159-226.

Munier-Chalmas, M. (1874). On the development of the phragmostracum of the Cephalopoda, and on the zoological relations of the ammonites to the Spirulae. The Annals and Magazine of the Natural History, 13(74), 180-188.

Mutvei, H. (1964). On the shells of Nautilus and Spirula with notes on the shell secretion in non-cephalpod molluscs. Arkiv för Zoologi, 16(14), 221-278.

Naef, A. (1922). Die fossilen Tintenfische-Eine paläozoologische Monographie (p. 322p). Jena: Gustav Fischer.

Reitner, J., \& Engeser, T. (1982). Phylogenetic trends in phragmocone-bearing coleoids (Belemnomorpha). Neues Jahrbuch für Geologie und Paläontologie Abhandlungen, 164, 156-161.
Ristedt, H. (1971). Zum Bau der Orthoceriden Cephalopoden. Palaeontographica A, 137(4-6), 155-195.

Sutton, M., Perales-Raya, C., \& Gilbert, I. (2015). A phylogeny of fossil and living neocoleoid cephalopods. Cladistics, 32(3), 297-307.

Sweet, W. C. (1964). Cephalopoda-general features. In C. Teichert, B. Kummel, W. C. Sweet, H. B. Stenzel, W. H. Furnish, B. F. Glenister, et al. (Eds.), Treatise on Invertebrate Paleontology. Part K. Mollusca 3. Cephalopoda-General features. Endoceratoidea-Actinoceratoidea-Nautiloidea-Bactritoidea (pp. 3-14). Lawrence, Kansas: Geological Society of America \& University Kansas Press.

Tanabe, K., Kulicki, C., \& Landman, N. H. (2008). Development of the embryonic shell structure of Mesozoic Ammonoids. American Museum Novitates, 3621, 1-19.

Tanabe, K., \& Uchiyama, K. (1997). Development of the embryonie shell structure in Nautilus. The Veliger, 4(3), 203-215.

Tanner, A. R., Fuchs, D., Winkelmann, I. E., Gilbert, M. T. P., Pankey, M. S., Ribeiro, A. M., et al. (2017). Molecular clocks indicate turnover and diversification of modern coleoid cephalopods during the Mesozoic Marine Revolution. Proceedings of the Royal Society B, 284(1850), 20162818.

Walch, J. E. I. (1768). Die Naturgeschichte der Versteinerungen zur Erläuterung der Knorrischen Sammlung von Merkwürdigkeiten der Natur, Theil 2, Abschnitt 1. Von Ammoniten und Nautiliden Nürnberg: Felssecker.

Warnke, K., \& Keupp, H. (2005). Spirula-a window to the embryonic development of ammonoids? Morphological and molecular indications for a palaeontological hypothesis. Facies, 51, 60-65.

Zakharov, Y. D. (1972). Formation of the caecum and prosiphon in ammonoids. Paleontological Journal (Translation of the Paleontologicheskiy Zhurnal), 6(1), 201-206. 